\title{
Transformation of Z-Generation in the context of globalization and place marketing: the case of Hungarian students
}

\author{
https://doi.org/10.21272/sec.4(1).28-35.2020
}

\author{
Urbánné Treutz Ágnes, ORCID: https://orcid.org/0000-0001-8604-9064
}

PhD Student, Assistant Lecturer, Department of Marketing Management, Faculty of Economics and Social Sciences, Szent István University, Hungary

\begin{abstract}
Considering that in most cases graduates of higher educational establishments stay and work in small settlements, the potential target audience for the use of territorial marketing tools is the student as representatives of generation $\mathrm{Z}$. The main characteristics of generation $\mathrm{Z}$ in the article are determined emotional lability, decision making, rejection and relative resilience in stressful situations, constant search for self-identification, multitasking, communication difficulties and, reducing attention spans and ongoing online presence on social media. The article uses the results of bibliometric analysis of scientific publications of scientists and researchers from Hungary, as well as the data of the Hungarian Youth Survey 2016 (its representative sample is 8000 respondents aged 18 to 29 years). The Hungarian student body (as a target audience for the use of territorial marketing tools) was researched by age, median income, attitudes to religion, family status, number and composition of households, leisure activities, emotional attachment to a particular territory. When introducing the concept of territorial marketing, it is important to take into account such features of the student body as determination and, in most cases, financial dependence on parents, therefore, mechanisms for improving the financial support of this category of population are considered, taking into account the strategic goals of territorial development. When formulating marketing policies, it is important to take into account globalization processes and their impact on different spheres of regional development. The results of the study are of practical importance and can be used by local authorities in developing a marketing and branding strategy for regional development.
\end{abstract}

Keywords: students, Z-Generation, consumer behavior, territorial marketing, regional branding, regional development strategy.

JEL Classification: M30, M31, F6.

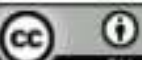

Cite as: Urbánné Treutz Ágnes (2020). Transformation of Z-Generation in the context of globalization and place marketing: the case of Hungarian students. SocioEconomic Challenges, 4(1), 28-35.

https://doi.org/10.21272/sec.4(1). 28-35.2020.

(C) The Author, 2020. This article is published with open access at Sumy State University.

\section{Introduction}

By selling any product or service it is important to segment and examine the market properly. This may lead us to better recognize the target group for which we would like to sell. This works in the same way for place marketing as well. In the case of the settlements we can distinguish three main target groups: the local residents, the tourists and the entrepreneurs. One of main aim of place marketing is to maintain and raise their life quality and living standards. The local residents get an emphasis in the perspective of settlements as by through their attraction the population of the settlement could rise, which in turn could change the population's demographical-social combination. Due to this it is important to observe any potential target group, whose members are just about to settle down, create families and start their jobs. This paper helps to better recognize this target group. The $\mathrm{Z}$ generation is this target group, who are in constant connection with the World Wide Web, primarily communicate through the internet, desire new and interesting stimuli and experiences. They seek to instantly satisfy these desires. The fast reaction is an important feature of the $\mathrm{Z}$ generation. The rapidity at the same time reduces the capability of exactitude, the turning over of a given factor, the engrossment in a topic. 


\section{Methodology}

The method of the research is the analysis of several scientific literature. There was an overview on Hungarian researches in this topic that specified the examined target group in great detail, which secured a good basis for a future research in the case of Hungarian students. Among the showcased researches the role of the Hungarian Youth Research 2016 is the most emphasized, which used a representative sample of 8000 respondents among the 15-29 year old people. They examined the basic motivations and indicators of starting a family, or having children; furthermore the education situation of the youths, their plans for further education and also touched upon their labour market opportunities, consumer behavior. They had deeper look on the leisure activities and spaces of the young people, their cultural consumption, internet access and use. The research was based on descriptive statistical results where they conducted comparative and trend analyses.

\section{The Z-generation's characteristics}

It is important to examine students as a potential target group's characteristics in the case of place marketing. Knowing the characteristics of the consumer gives the basis of the market segmentation. (Braun, 2008) The students who currently attend universities, are the members of the Z-generation, who were born after 2001. (Reeves - Oh, 2008) According to other definitions, the members of the Z-generation are those who were born from the mid of 1990s. (http://socialmarketing.org). We can call the Z-generation as "internetgeneration", because their members have never lived without access to the internet and mobile phones. It is specific to the generation that the tools of the information society have changed their habits (e.g.: less physical activity in social life, more time spent in the online space), the culture (e.g.: the digital tools which are used by cultural institutions helps experience tourism to be more multi-layered). (Székely, 2013) „The difference of the cultural consumer opportunities is significant mainly between the residents of Budapest and the countryside. The difference which concerns the whole social group (the youth generation) is the relationship with the information society. The digital socialization is already apply by the Y generation, but culminates between the members of Z-generation, the info-communication tools are part of their natural life." (Székely, 2013, p. 31-32.) Digitalization and the various new technologies appear in almost all parts of their life (from the education until the entertainment), which is why Prency calls them "digital natives". The youths are in continuous connection with the World Wide Web (,always on world"), and they have desires for interesting, new stimuli and experiences. They would like to immediately satisfy these occurring desires or needs. The fast reaction is a very important characteristic of the Z-generation, which primarily appears as their internet use. The rapidity at the same time reduces the capability of exactitude, the turning over of a given factor, the engrossment in a topic. Rapidity generates the so-called conveying-effect and generates addiction. The conveying-effect refers that the habitual, better quality product is relied by the quickly producible, easy accessible (e.g.: the semi-finished food the long time made food). The addiction, which means dependence refers how the attitude happens to the rapidity. They are so used to rapidity, that individuals become anxious if a train is a few minutes late, or if a given website does not load in a few seconds. The lack of rapidity could make it easier for the consumer to feel eagerness and anxiety. (Szabados, 2009; Small, 2009; Tari, 2011) This is why simplification, and getting straight to the point are important in the communication with the generation. (Töröcsik, 2010) The multitasking is specific for this generation, namely they are able to participate in multiple activities through shared attention, although the latter characteristic is that their attention is limited for only a little while. (Rab, 2007) „The interknit, parallel activities could break up the attention, so some of their elements could clog into the background." (Rab, 2007, p. 195.) The numerous new stimuli and spliced attention entails that they cannot receive all information in the same extent, so their attention is partial and continuously shared. (Szabados, 2009) While members of the Z-generation generate information themselves, they are also information-hungry. They satisfy these needs in a lot of cases through their interactive presence in the online space. This generation has a great need for this and also for the interactivity in the physical space, overlaying into the processes. (Törőcsik et al., 2014)

The Z-generation communicate primarily through the internet. As most often they use various chat-programs and social media interfaces to do this - where short, informal communication takes place with the use of emojis (emotional expressive) -, their communicational skills and attention capacity decrease. Despite their presence in the online network, the Z-generation's members we can better defined as individuals, rather than team-players. Even so the coeval groups, their norms are still important to them, their acts are seen as standards. (Tari, 2011) According to this is typical that they open up more towards their peers than their parents. (Töröcsik, 2010) To have a fellowship is important for the young people. (Székely - Szabó, 2017) 
The opinion leaders have important roles near the reference group in the life of Z-generation, who are stand out usually from the same age group. Both groups (reference group, opinion leaders) influence them in their behavior and habits. The trends form and change quickly, with whom the generation would like to keep in line. Their approach: if they miss out, they will drop out. These young people are afraid from lagging behind, and this fear forms their decision and taste. This causes them to imitate others, primarily the opinion leaders. There is a continuous willingness of adequacy between the members of the generation and in parallel the desire to raise others' attention. (Tari, 2011; Törőcsik et al., 2014) „The target group's attention is the most important short supply in the information society." (Tari, 2011, p. 61.) The young people try to raise this attention with the presence in the virtual space. Not only the attention but also the feedback is important for them. The lack of solving conflicts and problems is specific for the members of Z-generation. Because of the fast reactions they generate fast decisions, which results in hesitancy, thus they expect continuous feedback from their environment. (Tari, 2011)

Young people compose an independent social class in the modern society, for whom adolescence is further extended and appreciated. It is similar in the case of Z-generation, who - if they go study to a university - get into the world of work when they are 22-25 years old. The youths create the values and samples, which they take as a basis during career development. The institutions (e.g.: family, school), which could serve to control the individual are less determinative in their life, it is rather the mass media that plays a role shaping their values. The long-term learning brings the extension of dependent manner of life, with no recourses. Therefore in their case the free time has big value. (Arnold, 2011) According to Töröcsik (2010) the satiation of free time activity shows the real difference between certain generations. According to the results of the Hungarian Youth Research from 2016; the young people's (15-29 years old) free time activities consist of primarily watching the television, while the second place is internet and computer use. These screen activity push the more active free time activities (e.g.: sports, hiking, gadgeteering) significantly into the background. Chatting, using Facebook take the third place of the ranking, which is what more than 50\% of the respondents do in their free time. This refers to the continuous online presence of the Z-generation, which is not only reflected in their daily routine activities but also in the focus of their free time activity as well. The youths' weekday and weekend free time activity shows similar results, with the exception of hanging out with friends, conversing and hiking, which show greater occurrence in the weekend than in the weekdays. This may be due to the amount of free time, as during the weekend there is more time to take part in larger trips or to organize other programs with friends. It is interesting data that relatively bigger proportion of the respondents - more than $20 \%$-, gave the answer that they are "just getting by" in their freetime, which is mostly specific for those who live in the capital. On the one hand this could be derived from the youth living in a flat and not doing anything around the house, but in the other hand it could be derived from the different mentality (residents of larger cities tend to be more shut in than those of villages (Józsa, 2009)). Digitalization leads the youth to read less and less and have less books. In the case of attendance of cultural spaces the youth are going mainly to the multiplex cinemas (58\%) which is followed by going to concerts (46\%). More than $60 \%$ of the respondents almost never go to libraries, exhibitions, museums or theatres. All of this is thanks to digitalization, as almost everything is available to view online, while at the same time it is important to mention that nowadays young people are not interested in visiting museums and theatres. The virtual space, where numerous information and stimuli reach them in simultaneously, has a bigger impact on them. They lost their interest in the previously mentioned cultural activities (e.g.: theatre play, visiting exhibition, reading book), which furthermore mean less in terms of value for them. This is because of the generation's characteristics. For instance, book reading takes a lot of time, the anagnorisis does not appear immediately, which are all characteristics that oppose the Z-generation (which places emphasis on rapidity and immediate informationhunger). Most of the youths are going to pubs, wine taverns most commonly to talk with their friends. (Székely Szabó, 2017) The reason of this could be that they find it easier to afford consuming in a pub than in a restaurant, if they have moderate independent income or the lack of income. The free time means a sort of autonomy, self-realization for the youth which is important because one of biggest problem of the Zgeneration is the identity searching. (Töröcsik, 2010; Töröcsik et al., 2014). It could be thanks to slurring social roles, the lingering youth (which results longer hesitancy and more and more decisions made in the individual's life). The hesitancy reveals itself in the distress of young people (continuous willingness to comply with) (e.g.: the constant posting is a tool for the youths as a sort of anxiety reduction). (Arnold, 2011; Tari, 2011) All of the above makes them easy to influence. (Törócsik, 2010) During searching identity, they go through a socializing process, in the course of which they light upon themselves, find their values, evolve 
their relationships and companionship, all the while also acquiring knowledge and planning their careers. (Töröcsik et al., 2014) It is important to notice that as there is not yet an evolved definite, individual approach, the individuals are formed during the process, so they could be emotionally unstable. One characteristic of the $\mathrm{Z}$-generation is that the real attachment, the confidence is often missing from their relationships. (Tari, 2011) The Hungarian Youth Research from 2016 confirms these examinations, which shows that young people have full reliance primarily towards their family $(70 \%)$, while at the same time $95 \%$ of the respondents' have moderate reliance towards their family members. The full reliance significantly drops off in the other cases, like in the case of acquaintances (28\%), or neighbors (25\%). While $89 \%$ of the respondents rely moderately on their acquaintances, $81 \%$ of them rely the same way only $81 \%$ on their neighbors. The reason for this may be due to the different housing conditions (different social, economic conditions, village-city difference while in the village everyone knows who they live together in the community, the same is not so obvious in cities). On the topic of the absence of trustworthy relationships, it is worthwhile to mention that only $66 \%$ of the respondents have confidence towards the mayor of the settlement, the importance of which should be noted as they lack the cogency in the decision of the youth to stay in the settlement or not. It is also important to pay attention to what kind of marketing communication tools the settlement may use instead of personal "selling" to address the young people. Especially as we cannot reach members of the Z-generation with conventional advertisements, instead they are available primarily through internet applications and with the tools of guerrilla marketing. (Tari, 2011)

Great importance should be ascribed to the globalism in the life of young people. Globality is present in their life (homo globalis), which creates a new sorbing, which appears through the word usage, in the fashion, in the dishes, in the culture. (Bauer, 2011; Töröcsik et al., 2014) This implies that the culture is connected not to a given place, it rather breaks away from the place the same way as human connections break away from real life meetups and personal presence thanks to the internet. (Vermes, 2012) This is all very important in the case of examining young people's place attachment, because if we were to assume that they are more tied to the culture than to the place, it would face the settlements against significant difficulties in their efforts to attract and keep young people.

Overall Figure 1 summarizes the main characteristics that are mostly typical for the Z-generation.

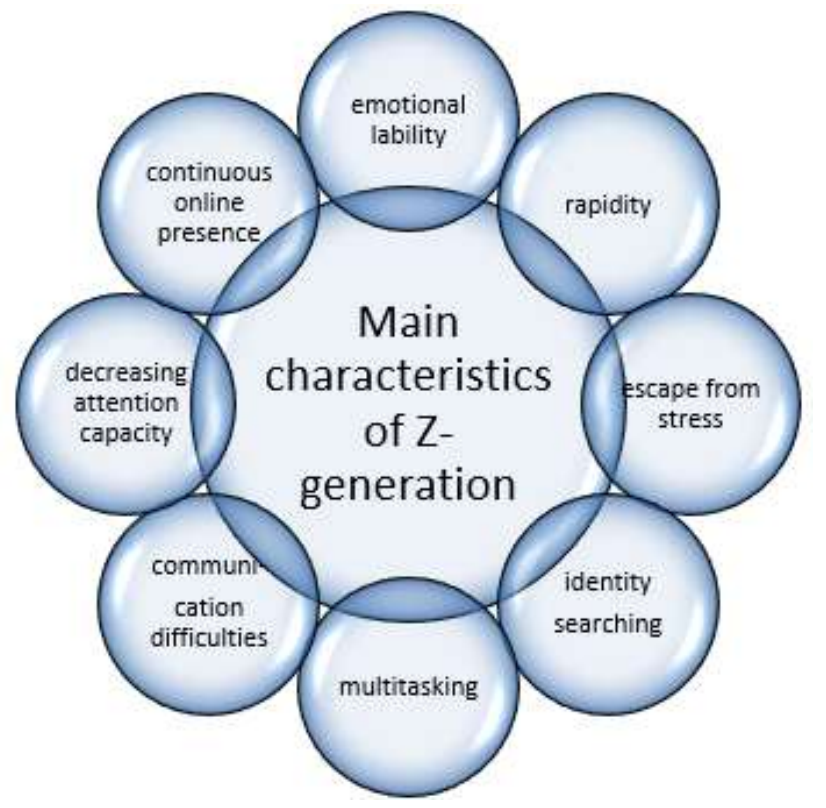

Figure 1. Main characteristics of the Z-generation

Source: Own elaboration, 2020.

\section{The students as the members of Z-generation}

The students as members of the Z-generation are in a special situation, where they are between the teen-ages and adulthood, they are in a so called post-adolescent life stage. This is a new form of life style, which has independent style notes that were formed independently by the youth themselves, inside their social groups. 
The reasons behind the post-adolescent life stage introduced by Keniston in his research between 1968 and 1989, are the aforementioned longer learning time and the consequentially later made commitments for work and responsibility. It is specific for this life stage that the independence from the parental home has not yet materialized (mainly the material independence), even if the youth lives separately from the parents (rent or dorm), while at the same time, a detachment process does start in certain other aspects of life (intellectual, social, political, moral, sexual). (Vaskovics, 2000; Zinnecker, 1982) „The present orientation is typical for these young people's behavior and life style, the compromise and pursuit for safety is missing." (Vaskovics, 2000 , p. 4.) We cannot generalize the post-adolescent life stage for a given age group. It may start from the age of 18 , however, may also appear even above the age of 30 . It is hard to even roughly estimate the age group limit, because the classification depends on the young adults' psychosocial development and sociocultural lifestyle. (Vaskovics, 2000).

While the students are still looking for their identity, they meet with many new situations, which they try to either adapt or reject. Merton (1980) examined the types of individual adaptation modes, where he distinguished five types (conformity, innovation, ritualism, retreatism and rebellion). Kozma (2004) took it as a basis to classify the five groups of students' behavior:

- conformity: the students adopt the tools used by the organization and identify themselves with the organization's objectives;

- innovation: the students do not accept the sanctioning tools used by the organization, but at the same time, they can identify themselves with the organization's objectives;

- ritualism: the students accept the tools used by the organization, but they do not identify themselves with the goals of the organization;

- retreatism: the students do not accept the tools used by the organization and they do not identify themselves with the goals of the organization;

- rebellion: the students do not accept the tools used by the organization and do not identify themselves with the goals of the organization, but contrary to the retreatism, they are willing to use new tools and objectives.

These groups of students' behavior are illustrated in the Table 1:

Table 1. The groups of students' behavior

\begin{tabular}{|l|c|c|}
\hline \multirow{2}{*}{ Used tools } & \multicolumn{2}{|c|}{ The organization's objective } \\
\cline { 2 - 3 } & identifying & do not identifying \\
\hline accept & conformity & ritualism \\
\hline reject & innovation & retreatism, rebellion \\
\hline
\end{tabular}

Source: According to Kozma (2004) own elaboration, 2020.

The students' behavior and the identification with the objectives of organization is important on the one hand in the identity searching process of the individual, on the other hand, it may be important in the terms of conformation of place identity. The place identity can be construed in settlement, county, regional, national or even higher level. The Hungarian Youth Research in 2016 examined the national identity and pointed out that young people are typically proud of their Hungarian nature and love their country. It is worth to highlight that there is a growing tendency regarding almost all of the observed signals - both in the patriotism and the pride towards the country. The only exception to the above is in the case of "love Hungarian language" as a factor, where that we may find a somewhat decreasing tendency. The latter point can be attributed to the continuous appreciation of the foreign languages, and also to the spread of slang inside the Z-generation, which entails the further decrease of the previously mentioned communication skills. The research highlights that compared to 2012, the proportion of those who would like to spend most of their lives in Hungary has increased. Behind this result lies the aforementioned strengthening of national identity, but at the same time it could also be due to certain political, economic actions which may also be influencing factor. An example being, the government funded family support programs (e.g.: Family homemaking discount), which may support the young couples to start a family. 
If we consider the factors that tie the young people to the parental house, we can better understand their behavior and characteristics. Vaskovics (2000) distinguishes the following types of detachment from the parental house:

- separation from the common roof: moved out from the parental house and managing an independent household;

- legal sense of detachment: reaching the age of 18 and the following ceasing of parental care, guardianship, the freedom of transactions and legally permitted participation in the political life;

- own decision leading to detachment: action and participation without parental control in all areas of life (economic, political, cultural), which is achieved, inter alia, in career choice, mate choice, residence and housing choice;

- subjective detachment: the individual feels himself/herself as a grown-up, which may occur when the age of majority is reached, or later, regardless whether the cases of detachment have happened or not. These may depend on a given society and culture;

- financial detachment: financial independence through own earnings and work place.

The students may still be related to the parents' house in terms of financial and residence, the legal separation has occurred in their case, their own decision leading to detachment has partly happened since they have chosen a career but have not yet decided on the new place to live and actual home. The subjective detachment may vary individually, so this factor cannot be assessed with objective data.

\section{The local residents' characteristics, taking into account the potential local residents}

It is worth to examine the local residents' characteristics from the place marketing's point of view, which we can couple with the potential target group's, the students' attributes. According to Braun (2008) the potential residents' characteristics are defined by the following factors: composition of household, age, income, race, religion, family ties, educational background, coeval groups, emotional attachment to a community. The composition of the household may consists of a married couple, a family with children, a single person, or other, people cohabitation from forms (e.g.: students rent an apartment together). The local residents' age structure is different in each case. The age determines significantly the way of life and the lifestyle (e.g.: an old and a young married couple will have different needs). Household income is one of determining factors of the consumer's way of life. The available income determines the spending limits, so it significantly limits the housing, lifestyle, and leisure opportunities. (Braun, 2008)

Depending on all of these, we can determine the characteristics in the case of students as potential local residents, which shows the Table 2.

Table 2. The students as potential residents' consumer characteristics

\begin{tabular}{|l|l|}
\hline \multicolumn{1}{|c|}{$\begin{array}{c}\text { The determining factors of local residents' consumer } \\
\text { characteristics }\end{array}$} & \multicolumn{1}{c|}{ In the case of students as potential residents } \\
\hline Composition of household & he/she lives with parents \\
\hline Age & $18-25$ years old \\
\hline Income & there is no or minimal independent income (e.g.: student work) \\
\hline Religion & individually various \\
\hline Family ties & subjective, individually various \\
\hline Educational background & ongoing higher education studies \\
\hline Coeval groups & $\begin{array}{l}\text { university communities, hobby-related communities, apartment } \\
\text { community, other }\end{array}$ \\
\hline Emotional attachment to a community & individually various \\
\hline
\end{tabular}

Source: Own elaboration, 2020.

With the exception of the subjective individual factors (religion, family ties, emotional attachment to a community), the objective factors may be generalized, thus the age, financial dependence, and the not yet independent household existence. These factors refer to the previously presented characteristics outlined by Vaskovics (2010), which are the characteristics of the post-adolescent lifestyle. 


\section{Conclusions}

Overall through the study's examination of the Z-generation's main characteristics, we can highlight the following: emotional lability, rapidity, escape from stress, identity searching, multitasking, communication difficulties, decreasing attention capacity, and continuous online presence. Apart from the above, it may also be concluded that the students like the Z-generation's members are in the post-adolescent life stage, namely they are between the teen-ages and adulthood. Their main feature is that they are still not independent, in most cases they are financially still tied to their parents. Their detachment can be distinguished in five areas: separation from the common roof, legal sense of detachment, own decision leading to detachment, subjective detachment, financial detachment. As the students are a potential target group from the perspective of place marketing, it is important to have a clear view on their characteristics, and also to outline the features that are specific to the students as potential local residents. Based on the above we can say that the composition of the household, the age, the income, the educational background may all be factors that can be taken into account as objective factors in later empirical research.

\section{References}

1. Arnold, P. (2011). A szülői háztól való leválás és a drogfogyasztás vizsgálata a fiatal felnőtt populáció körében [Examination of parental home detachment and drug use among the young adult population]. in: Bauer, B., Szabó, A. (eds.) (2011). Arctalan (?) nemzedék. Ifjúság 2000-2010. [Faceless (?) Generation. Youth 2000-2010]. Nemzeti Család- és Szociálpolitikai Intézet [National Institute for Family and Social Policy], Budapest. p. 185-207. https://barankovics.hu/_f/honlapra/arctalan-nemzedek-1.pdf

2. Bauer, B. (2011). A kulturális szemlélet spiráljai. A magyar fiatalok kulturális és szabadidös szokásainak különbözöségei az ezredfordulón [The spirals of cultural perspective. The Hungarian youths' dissimilarities of cultural and leisure habits in the millenium]. in: Bauer, B., Szabó, A. (eds.) (2011): Arctalan (?) nemzedék. Ifjúság 2000-2010. [Faceless (?) Generation. Youth 2000-2010]. Nemzeti Családés Szociálpolitikai Intézet [National Institute for Family and Social Policy], Budapest. p. 221-247. https://www.felvi.hu/pub_bin/dload/felsooktatasimuhely/FeMu/2013_3_4/femu_2013_3_4_3140_csozik.pdf

3. Braun, E. (2008). City marketing. Towards an integrated approach. Erasmus University, Rotterdam. 250 p. https://www.academia.edu/34967928/ERIK_BRAUN_City_Marketing_Towards_an_integrated_approa ch_ERIM_PhD_Series_Research_in_Management_CITY_MARKETING_TOWARDS_AN_INTEGR ATED_APPROACH

4. Józsa, K. (2009). Települési versenyképesség, települési siker [Settlement competitiveness, settlement success]. Jelenkori Társadalmi és Gazdasági Folyamatok [Contemporary Social and Economic Processes], (3-4), 224-228. https://ojs.bibl.u-szeged.hu/index.php/jelenkori_tarsgazd folyamatok/article/view/32367/31870

5. Kozma, T. (2004). Kié az egyetem? [Who owns the university?] Új Mandátum Felsőoktatási Kutatóintézet [New Mandate Research Institute], Budapest. 242 p. http://mek.oszk.hu/08900/08962/08962.pdf

6. Merton, R. K. (1980). Társadalomelmélet és társadalmi struktúra [Society theory and society structure]. Gondolat Kiadó [Gondolat Publisher], Budapest. https://bookline.hu/product/home.action?_v=Robert_K_Merton_Tarsadalomelmelet_es_t\&type=22\&id= $\underline{8343}$

7. Rab, Á. (2007). Digitális kultúra [Digital culture]. in: Pintér, R. (ed.) (2007). Az információs társadalom [The information society]. Gondolat Kiadó [Gondolat Publisher], Budapest. p. 192-200. http://www.artefaktum.hu/Pinter_PhD_v2.pdf

8. Reeves, T. C., Oh, E. (2008). Generational differences. in: Spector, J. M., Merrill, M. d., Merriënboer, J. V., Driscoll, M. P. (eds.) (2008). Handbook of Research on Educational Communications and Technology Lawrence Erlbaum Associates, New York. p. 295-304. http://citeseerx.ist.psu.edu/viewdoc/download?doi=10.1.1.183.8451\&rep=rep1\&type=pdf

9. Small, G., Vorgan, G. (2009). iBrain: Surviving the Technological Alteration of the Modern Mind. Harper Collins, New York. 240 https://commons.pacificu.edu/cgi/viewcontent.cgi?article $=1005 \&$ context=inter09

10. Szabados, S. (2009). Digitális bennszülöttek [Digital natives]. Oktatás - Informatika [Education Computer Science], 1 (1), 19-23. http://www.eltereader.hu/media/2013/05/Okt_Inf_2009_1_opt.pdf 
11. Székely, L. (2013). Média multitasking [Media multitasking]. Az új generációk megváltozó médiafogyasztási és kommunikációs szokásairól [About the changing media consumption and communication habits of the new generations]. Ph.D. értekezés [PhD Thesis]. Corvinus Egyetem [Corvinus University], Budapest. 215 p. http://phd.lib.uni-corvinus.hu/766/1/Szekely Levente.pdf

12. Székely, L., Szabó, A. (eds.) (2017): Magyar Ifjúság Kutatás 2016. Az ifjúságkutatás első eredményei [Hungarian Youth Research 2016. The first results of the youth research]. Új Nemzedék Központ [New Generation $\quad$ Centre], $\quad$ Budapest. $\quad 99 \quad$ p. https://www.ujnemzedek.hu/sites/default/files/magyar_ifjusag_2016_a4_web.pdf Accessed: 24. January 2020.

13. Töröcsik, M. (2010). A fiatalok fogyasztói magatartása - Az egyetemek fő célcsoportjának megértése [The consumer behavior of youths - Understanding the main target group of the universities]. in: Töröcsik, M., Kuráth, G. (eds.) (2010). Egyetemi marketing. Marketing a felsöoktatásban [University marketing. Marketing in the Higher Education]. Pécsi Tudományegyetem [University of Pécs], Pécs. p. 123-139. https://www.slideshare.net/PTE1367/egyetemi-marketing-felsoktatsban

14. Töröcsik, M., Szücs, K., Kehl, D. (2014). Generációs gondolkodás - A Z és az Y generáció életstílus csoportjai [Generation thinking - The lifestyle groups of the $\mathrm{Z}$ and the $\mathrm{Y}$ generation]. Marketing \& Menedzsment [Marketing \& Management]. II. különszám [II. Special Issue]. p. 3-15. https://journals.lib.pte.hu/index.php/mm/article/view/861/732

15. Vaskovics, L. (2000). A posztadoleszcencia szociológia elmélete [The sociological theory of postadolescence]. Szociológiai Szemle [Review of Sociology of the Hungarian Sociological Association]. No. 2000/4. p. 3-20. http://szociologia.hu/dynamic/VaskovicsL_tanulmany.pdf

16. Vermes, K. (2012). A jelen pillanat. Felpörgött idő és terápiás jelen a posztmodern kultúrában [The present moment. Accelerated time and therapeutic present in the post modern culture]. IMÁGÓ Budapest. 23(2), 47-66. http://imago.mtapi.hu/a_folyoirat/e_szovegek/pdf/2(23)2012-2/047-66_Vermes-K.pdf

17. Zinnecker, J. (1982). Jugend 1981: Porträt einer Generation [Youths 1981: Portrait of a Generation]. in: Jugend '81. Lebensentwürfe, Alltagskulturen, Zukunftsbilder [Youths '81. Life plans, Everyday cultures, Vision for the future]. Jugendwerk der Deutschen Shell, Hamburg. p. 80-122. https://link.springer.com/chapter/10.1007/978-3-322-95481-7 5.

\section{Online source}

Schroer, B. Generations X,Y, Z and the Others. http://socialmarketing.org/archives/generations-Xy-Z-and-theothers/ Accessed 24. January 2020. 